\section{Pruning Landscape Palms}

\author{
A. James Downer ${ }^{1,3}$, Donald R. Hodel ${ }^{2}$, \\ and Maren J. Mochizuki ${ }^{1}$
} ADDITIONAL INDEX WORDS. california fan palm, disease control, mexican fan palm,
queen palm, sanitation, windmill palm

SumMARY. Landscape palms (Arecaceae) are pruned (i.e., leaves removed) to avoid the hazard of falling fronds, to remove diseased or brown leaves, and, in some cases, to minimize growth by diminishing photosynthetic capacity. In studies at two California locations (Long Beach and Irvine), even complete leaf removal every 3 to 4 months for 18 to 21 months resulted in similar new leaf production by queen palm (Syagrus romanzoffiana) or windmill palm (Trachycarpus fortunei) compared with no pruning or " 10 and 2 " pruning (industry standard pruning referring to the palm canopy visually beginning at the 10 o'clock position and ending at the 2 o'clock position on a clock face). By contrast, complete leaf removal reduced the number of new leaves of california fan palm (Washingtonia filifera), young mexican fan palm [MFP ( Washingtonia robusta)], and taller, more mature MFP by $30 \%$, $23 \%$, and $21 \%$ compared with no pruning and " 10 and 2 " pruning. Leaf petiole length, leaf blade length, leaf blade width, and total palm height were also reduced $19 \%$ to $43 \%$ after complete leaf pruning compared with no and " 10 and 2 " pruning of young and more mature MFP. Although " 10 and 2 " pruning did not reduce growth of any palms, pruning all but the four newest leaves reduced leaf petiole length by $21 \%$ for the taller MFP. An important consideration for palm disease control is that tools used for pruning may harbor pathogen inoculum. Flaming pruning saws with a propane torch for $10 \mathrm{~s}$ reduced total fungal colonies and palm pathogenic fungi recovered on a selective medium by $95 \%$. Increasing our understanding of palm response to leaf removal and how to minimize unintended consequences of pruning, such as the spread of disease, is an important part of improving palm maintenance.

$\mathrm{P}$ alms are arborescent monocotyledons that do not usually branch along their stem. Consequently, pruning landscape palms is essentially the removal of inflorescences and leaves from the lower portion of the canopy or, in the case of multiple trunked species, the removal of entire stems.

Palms are pruned for several reasons. Palm owners often want to "get their money's worth" from a pruning operation, such that palms are often radically pruned to remove all or most leaves. Although severe pruning is thought to negatively impact on the palm, complete leaf removal on sabal palm (Sabal palmetto) and pygmy date palm (Phoenix roebelenii) reduced transpiration water loss before transplanting (Broschat, 1991, 1994a). Furthermore, some landscapes require

\footnotetext{
${ }^{1}$ University of California Cooperative Extension, 669 County Square Drive, Suite 100, Ventura, CA 93003

${ }^{2}$ University of California Cooperative Extension, 4800 East Cesar Chavez Avenue, Los Angeles, CA 90022

${ }^{3}$ Corresponding author. E-mail: ajdowner@ucdavis. edu.
}

that no fronds drop to the ground to minimize hazard; therefore, it is not uncommon for palms to be pruned four times within a single year in southern California. Palms may also be pruned many times per year in an effort to control growth (Robinson, 2004). For example, Broschat and Meerow (2000) assert that removal of healthy palm leaves may lead to reduction in trunk caliper at the meristem. In macronutrient-deficient trees, removal of older palm leaves increased the severity of the deficiency in the remaining leaves and thus reduced the growth of the palm overall (Broschat, 1994b).

Current recommendations include pruning only dead, badly damaged or diseased leaves (Broschat and Meerow, 2000). Although removal of diseased leaves is sometimes recommended as a way to limit the development of diamond scale (Phaeochoropsis neowashingtoneae), severity of infection of california fan palm was not reduced even when all leaves were removed (Downer and Hodel, 2007). Hodel (1999) suggests removal of only brown leaves, cut neatly and close to the trunk, to avoid affecting the normal growth and development of the palm.

Another consideration during pruning is that tools may harbor disease inoculum. Palms are susceptible to a number of diseases caused by fungi (Downer et al., 2009; Elliot et al., 2004), some of which require a wound or injury to infect [e.g., canary island date palm wilt (Fusarium oxysporum f. sp. canariensis)]. While several treatments have been recommended for sanitizing saw blades used to remove leaves from palms (Elliot, 2006), using liquids to sanitize blades has several drawbacks: soaking takes time, solutions require frequent changing to maintain efficacy, spent solutions must be disposed in a safe manner, and the solutions may corrode tools, thereby increasing costs.

Our objective was to evaluate leaf production and growth of common landscape palm species after frequent pruning treatments, ranging from the industry standard to severe leaf removal. We also propose a novel method of saw sanitation that avoids the use of caustic liquids.

\section{Materials and methods}

Pruning studies. Leaf removal studies were conducted at two California locations, Long Beach and Irvine. Leaves were trimmed as close to the trunk as possible using hand saws or pole-mounted saws with triedged blades (Corona Clipper,

\begin{tabular}{llll}
\hline $\begin{array}{l}\text { Units } \\
\text { To convert U.S. to SI, } \\
\text { multiply by }\end{array}$ & U.S. unit & SI unit & $\begin{array}{l}\text { To convert SI to U.S., } \\
\text { multiply by }\end{array}$ \\
\hline 0.3048 & $\mathrm{ft}$ & $\mathrm{m}$ & 3.2808 \\
3.7854 & $\mathrm{gal}$ & $\mathrm{L}$ & 0.2642 \\
2.54 & inch $(\mathrm{es})$ & $\mathrm{cm}$ & 0.3937 \\
1 & $\mathrm{ppm}$ & $\mathrm{mg} \cdot \mathrm{L}^{-1}$ & 1 \\
1 & $\mathrm{ppm}$ & $\mu \mathrm{L} \cdot \mathrm{L}^{-1}$ & 1 \\
$\left({ }^{\circ} \mathrm{F}-32\right) \div 1.8$ & ${ }^{\circ} \mathrm{F}$ & ${ }^{\circ} \mathrm{C}$ & $\left(1.8 \times{ }^{\circ} \mathrm{C}\right)+32$
\end{tabular}


Corona, CA). Before beginning pruning treatments, the newest expanded leaf was tagged with plastic tape on all palms; before each subsequent pruning, the number of leaves formed after the previously applied tape was counted and new tape was installed. We counted leaves and applied pruning treatments every 3 months for 18 to 21 months. The experimental design was a randomized complete block with a minimum of five replications. Analysis of variance was conducted using the Mixed Procedure in SAS (version 9; SAS Institute, Cary, NC) with the overall error rate controlled by TukeyKramer adjustment.

In 2002, we planted california fan palms (CFP) from 1-gal nursery containers in clay soil with $3-\mathrm{m}$ spacing at Long Beach. The palms grew undisturbed for 18 months so that about 2 $\mathrm{ft}$ of clear trunk was present before the following pruning treatments were applied: all leaves removed, all but the four newest leaves removed, and no leaves removed.

In 2003, we planted queen palm, windmill palm, and mexican fan palm from 1-gal containers in sandy loam with $5-\mathrm{m}$ spacing at Irvine. After 3 years, the amount of clear trunk ranged from 2 to $5 \mathrm{ft}$, depending on the species. The following pruning treatments were applied: all leaves removed, " 10 and 2 ," and no leaves removed. In Jan. 2008 (after about 21 months of pruning treatments), we measured pruned leaf petioles from the cut end to the hastula (where the petiole meets the blade) for MFP and windmill palm only. Leaf width was measured across its widest portion and leaf length was measured from the hastula to the blade tip. In Sept. 2008 (about 9 months after the last pruning treatment), we also measured MFP height (from ground to top of canopy).

A separate group of larger MFP $(7-10 \mathrm{ft}$ of clear trunk) were transplanted on $5-\mathrm{m}$ centers to Irvine in 2004. After 18 months of growth, the following pruning treatments were applied: all leaves removed, " 10 and 2 ," all but four newest leaves removed, no leaves removed. In Dec. 2007 (after 20 months of pruning treatments), we measured leaf dimensions as described above.

Tool sanitation. We verified the presence of the canary island date palm wilt pathogen in canary island date palm at Irvine by isolation and microscopic identification. Petioles from these palms were cut with a pole saw blade (9s; Fanno Saw Works, Chino, CA) to load the gullets of the saw blade with infested palm tissue. Flame from a propane torch (Type Z; Ace Hardware, Oak Brook, IL) was held 1 inch from the infested blade and moved along the blade for $0,10,20$, or $40 \mathrm{~s}$. Palm tissue particles from each cut were removed from blade gullets and placed on two plates of a selective medium of acidified $\left(500 \mu \mathrm{L} \cdot \mathrm{L}^{-1}\right.$ lactic acid) potato dextrose agar (BD Diagnostic Systems, Franklin Lakes, NJ) containing 50 $\mathrm{mg} \cdot \mathrm{L}^{-1} \quad$ pentachloronitrobenzene (Uniroyal, Middlebury, CT). Plates were incubated at $24{ }^{\circ} \mathrm{C}$ in the dark for 7 to $10 \mathrm{~d}$. The total number of fungal cfu, which included saprophytic and palm pathogenic fungi [canary island date palm wilt and pink rot (Nalanthamala vermoeseni) pathogen colonies] and the number of palm-pathogenic fungi only were counted. Counts from each plate (two plates per petiole cut, three petiole cuts, three replications of each flaming treatment for a total of 18 observations per treatment) were averaged before conducting one-way analysis of variance (Minitab 15; Minitab, State College, PA).

\section{Results}

Removal of all leaves from CFP at Long Beach reduced the number of new leaves by $30 \%$ compared with unpruned palms, while removal of all but the four youngest leaves did not change leaf production rate compared with unpruned palms $[P=0.05$ (Table 1)]. After 18 months, three palms with leaves completely removed died, and spores of the pink rot pathogen were present in the rotted buds. All other palms in the study continued to grow without bud rot.

At Irvine, queen palm, windmill palm, and MFP planted from 1-gal containers averaged 8,38 , and 83 new leaves, respectively after 18 months without any pruning (Table 2). Only MFP was significantly affected by pruning treatment: complete leaf removal reduced new leaf production by $23 \%$ and $30 \%$ compared with no pruning and " 10 and 2" pruning, respectively $[P<0.0001$ (Table 2$)]$. Between 3 and 6 months after initiating pruning treatments, we counted four and five fewer leaves in the complete removal and no removal treatments, respectively, compared with the " 10 and 2 " treatment $[P=$ 0.003 (Table 2)]. After 10 months of pruning, however, " 10 and 2 " pruning and no pruning resulted in similar number of leaves at each sampling date $[P<0.05$ (Table 2$)]$.

Taller and more mature transplanted MFP at Irvine pruned to " 10 and 2" or pruned to the four newest leaves produced similar numbers of new leaves to unpruned palms (Table 3). Complete leaf removal resulted in a $21 \%$ reduction in leaf production compared with the other treatments $[P=0.01$ (Table 3 )].

Leaf dimensions were similar for " 10 and 2" and unpruned MFP planted from l-gal containers as well as for the larger transplants (Table 4). Only complete leaf removal resulted in $19 \%$ to $27 \%$ reduction in leaf petiole length, blade length, and blade width for MFP planted from 1-gal containers $[P<0.05$ (Table 4 ) $]$. On the larger

Table 1. Number of new leaves after pruning california fan palm at Long Beach, CA. Before pruning, the newest expanded leaf was tagged with plastic tape; at each subsequent pruning, the number of leaves formed after the previously applied tape was counted and new tape was installed. There were six replications per treatment $(n=18)$.

\begin{tabular}{|c|c|c|c|c|c|c|}
\hline \multirow[b]{2}{*}{ Pruning treatment } & \multicolumn{6}{|c|}{ New leaves (no.) } \\
\hline & $\begin{array}{l}\text { Sept. } \\
2003\end{array}$ & $\begin{array}{l}\text { Feb. } \\
2004\end{array}$ & $\begin{array}{l}\text { June } \\
2004\end{array}$ & $\begin{array}{l}\text { Sept. } \\
2004\end{array}$ & $\begin{array}{l}\text { Feb. } \\
2005\end{array}$ & Total \\
\hline All leaves removed & 7 & 3 & $4 b^{z}$ & 7 & $2 \mathrm{~b}$ & $21 \mathrm{~b}$ \\
\hline $\begin{array}{l}\text { All but four newest } \\
\text { removed }\end{array}$ & 6 & 4 & 5 a & 8 & $4 \mathrm{a}$ & $27 \mathrm{a}$ \\
\hline No leaves removed & 6 & 3 & $6 \mathrm{a}$ & 8 & $4 \mathrm{a}$ & $30 \mathrm{a}$ \\
\hline$P$ value & NS & NS & 0.001 & NS & $<0.0001$ & 0.05 \\
\hline
\end{tabular}

${ }^{2}$ Means followed by the same letter within a column are not significantly different at $P<0.05$ with the overall error rate of analysis of variance controlled by Tukey-Kramer adjustment. 
Table 2. Number of new leaves after pruning queen palm, windmill palm, and mexican fan palm planted from 1 -gal (3.8 L) containers at Irvine, CA. Before pruning, the newest expanded leaf was tagged with plastic tape; at each subsequent pruning, the number of leaves formed after the previously applied tape was counted and new tape was installed. There were five replications per treatment $(n=15$ per species $)$.

\begin{tabular}{|c|c|c|c|c|c|c|c|c|c|}
\hline \multirow[b]{2}{*}{ Palm species } & \multirow[b]{2}{*}{ Pruning treatment } & \multicolumn{8}{|c|}{ New leaves (no.) } \\
\hline & & $\begin{array}{l}\text { Apr. } \\
2006\end{array}$ & $\begin{array}{c}\text { July } \\
2006\end{array}$ & $\begin{array}{l}\text { Nov. } \\
2006 \\
\end{array}$ & $\begin{array}{c}\text { Feb. } \\
2007\end{array}$ & $\begin{array}{c}\text { May } \\
2007\end{array}$ & $\begin{array}{l}\text { Aug. } \\
2007\end{array}$ & $\underset{2008}{\text { Jan. }}$ & Total \\
\hline \multirow{3}{*}{ Queen palm } & $" 10$ and $2 " \mathrm{z}$ & 0.2 & 2 & 2 & 0.6 & 0.6 & 2 & 1 & 8 \\
\hline & No leaves removed & 0.6 & 2 & 2 & 0.8 & 0.2 & 2 & 1 & 8 \\
\hline & $P$ value & NS & NS & NS & NS & NS & NS & NS & NS \\
\hline & No leaves removed & 4 & 7 & 9 & 3 & 4 & 6 & 6 & 38 \\
\hline & $P$ value & NS & NS & NS & NS & NS & NS & NS & NS \\
\hline \multirow[t]{4}{*}{ Mexican fan palm } & All leaves removed & 8 & 12 & $15 b^{y}$ & $4 \mathrm{~b}$ & $6 \mathrm{~b}$ & $9 \mathrm{~b}$ & $9 \mathrm{~b}$ & $64 \mathrm{c}$ \\
\hline & $" 10$ and $2 "$ & 8 & 13 & $20 \mathrm{a}$ & $7 \mathrm{a}$ & $11 \mathrm{a}$ & $17 \mathrm{a}$ & $15 \mathrm{a}$ & $92 \mathrm{a}$ \\
\hline & No leaves removed & 7 & 12 & $16 \mathrm{~b}$ & $7 \mathrm{a}$ & $13 \mathrm{a}$ & $16 \mathrm{a}$ & $14 \mathrm{a}$ & $83 \mathrm{a}$ \\
\hline & $P$ value & NS & NS & 0.003 & 0.03 & $<0.0001$ & $<0.0001$ & $<0.0001$ & $<0.0001$ \\
\hline
\end{tabular}

${ }^{z}$ Industry standard pruning referring to a clock face: if the palm is viewed in profile, the canopy would begin at the 10 o'clock position and end at the 2 o'clock position. ${ }^{y}$ Means followed by the same letter within a column are not significantly different at $P<0.05$ with the overall error rate of analysis of variance controlled by Tukey-Kramer adjustment.

Table 3. Number of new leaves after pruning transplanted mexican fan palm with 7 to $10 \mathrm{ft}(2.1-3.0 \mathrm{~m})$ of clear trunk at Irvine, CA. Before pruning, the newest expanded leaf was tagged with plastic tape; at each subsequent pruning, the number of leaves formed after the previously applied tape was counted and new tape was installed. There were seven replications per treatment $(\mathrm{n}=28)$.

\begin{tabular}{|c|c|c|c|c|c|c|c|c|}
\hline \multirow[b]{2}{*}{ Pruning treatment } & \multicolumn{8}{|c|}{ New leaves (no.) } \\
\hline & $\begin{array}{l}\text { Apr. } \\
2006\end{array}$ & $\begin{array}{c}\text { July } \\
2006\end{array}$ & $\begin{array}{l}\text { Nov. } \\
2006\end{array}$ & $\begin{array}{c}\text { Jan. } \\
2007\end{array}$ & $\begin{array}{c}\text { May } \\
2007 \\
\end{array}$ & $\begin{array}{l}\text { Aug. } \\
2007\end{array}$ & $\begin{array}{l}\text { Dec. } \\
2007 \\
\end{array}$ & Total \\
\hline All but four newest removed & $5.7 \mathrm{ab}$ & 9 & $18 \mathrm{ab}$ & 7 & $10 \mathrm{a}$ & $13 \mathrm{a}$ & $11 \mathrm{~b}$ & $73 a$ \\
\hline$" 10$ and $2 " y$ & $5.8 \mathrm{a}$ & 9 & $20 \mathrm{a}$ & 7 & $11 \mathrm{a}$ & $15 \mathrm{a}$ & $13 \mathrm{a}$ & $74 \mathrm{a}$ \\
\hline No leaves removed & $4.4 \mathrm{~b}$ & 9 & $18 \mathrm{ab}$ & 6 & $9 \mathrm{a}$ & $15 \mathrm{a}$ & $13 \mathrm{a}$ & $80 \mathrm{a}$ \\
\hline
\end{tabular}

${ }^{2}$ Means followed by the same letter within a column are not significantly different at $P<0.05$ with the overall error rate of analysis of variance controlled by Tukey-Kramer adjustment.

'Industry standard pruning referring to a clock face: if the palm is viewed in profile, the canopy would begin at the 10 o'clock position and end at the 2 o'clock position.

Table 4. Petiole length, blade length, and blade width of new leaves measured 20 months after pruning windmill palm and mexican fan palm with 2 to $5 \mathrm{ft}(0.6-1.5 \mathrm{~m})$ of clear trunk and 21 months after pruning a separate group of larger mexican fan palm with 7 to $10 \mathrm{ft}(2.1-3.0 \mathrm{~m})$ clear trunk at Irvine, CA. Before pruning, the newest expanded leaf was tagged with plastic tape; at each subsequent pruning, the number of leaves formed after the previously applied tape was counted and new tape was installed. Table values represent the mean of three leaves per replication $(n=15$ per species).

\begin{tabular}{|c|c|c|c|c|c|c|c|}
\hline \multirow[b]{2}{*}{ Trial } & \multirow[b]{2}{*}{$\begin{array}{l}\text { Pruning } \\
\text { treatment }\end{array}$} & \multicolumn{2}{|c|}{ Petiole length $(\mathrm{cm})^{\mathrm{z}}$} & \multicolumn{2}{|c|}{ Blade length $(\mathrm{cm})^{\mathrm{y}}$} & \multicolumn{2}{|c|}{ Blade width $(\mathrm{cm})$} \\
\hline & & $\begin{array}{l}\text { Mexican } \\
\text { fan palm }\end{array}$ & $\begin{array}{c}\text { Windmill } \\
\text { palm }\end{array}$ & $\begin{array}{l}\text { Mexican } \\
\text { fan palm }\end{array}$ & $\begin{array}{l}\text { Windmill } \\
\text { palm }\end{array}$ & $\begin{array}{l}\text { Mexican } \\
\text { fan palm }\end{array}$ & $\begin{array}{c}\text { Windmill } \\
\text { palm }\end{array}$ \\
\hline Palms with 2 to 5 & All leaves removed & $81 b^{x}$ & 13 & $94 \mathrm{~b}$ & 38 & $132 \mathrm{~b}$ & 53 \\
\hline $\mathrm{ft}$ of clear trunk & $" 10$ and $2 " w$ & $107 \mathrm{a}$ & 41 & $114 \mathrm{a}$ & 48 & $168 \mathrm{a}$ & 81 \\
\hline & No leaves removed & $114 \mathrm{a}$ & 43 & $117 \mathrm{a}$ & 51 & $165 \mathrm{a}$ & 81 \\
\hline & $P$ value & $<0.0001$ & NS & 0.0017 & NS & 0.0224 & 0.23 \\
\hline & $" 10$ and $2 "$ & $117 \mathrm{a}$ & & $119 \mathrm{a}$ & & $135 \mathrm{a}$ & \\
\hline & No leaves removed & $109 \mathrm{a}$ & & $107 \mathrm{ab}$ & & $135 \mathrm{a}$ & \\
\hline & $P$ value & $<0.0001$ & & 0.004 & & 0.0008 & \\
\hline
\end{tabular}

${ }^{2}$ Petioles measured from cut end to the hastula of the blade; $1 \mathrm{~cm}=0.3937$ inch.

y Blade measured from the hastula to the tip of the leaf.

${ }^{x}$ Means followed by the same letter within a trial and within a column and are not significantly different at $P<0.05$ with the overall error rate of analysis of variance controlled by Tukey-Kramer adjustment.

'Industry standard pruning referring to a clock face: if the palm is viewed in profile, the canopy would begin at the 10 o'clock position and end at the 2 o'clock position. 
MFP that were more severely pruned to the four newest leaves, leaf petioles were $21 \%$ shorter compared those from no pruning or " 10 and 2 " pruning treatments $[P<0.0001$ (Table 4)]. Complete leaf removal reduced petiole length $42 \%$ compared with no pruning or " 10 and 2 " pruning $[P<0.0001$ (Table 4$)]$. The " 10 and 2 " pruning also resulted in leaf blades about 25\% longer and wider compared with complete pruning, but was statistically similar to no pruning (Table 4). No pruning treatments, including complete leaf removal, affected leaf dimensions of windmill palm (Table 4 ).

Table 5. Height of mexican fan palm after six prunings during 18 months at Irvine, CA. Palms were measured in Sept. 2008, about 9 months after the last pruning. There were five replications per treatment $(n=15)$.

\begin{tabular}{lc}
\hline Pruning treatment & $\mathbf{H t}(\mathbf{m})^{\mathrm{z}}$ \\
\hline All leaves removed & $3.7 \mathrm{~b}^{\mathrm{y}}$ \\
"10 and 2"x & $6.4 \mathrm{a}$ \\
No leaves removed & $6.5 \mathrm{a}$ \\
$P$ value & $<0.0001$ \\
\hline
\end{tabular}

${ }^{2}$ Tree height measured from the ground to the canopy center at the point of leaf emergence; $1 \mathrm{~m}=$ $3.2808 \mathrm{ft}$

${ }^{y}$ Means followed by the same letter within a column are not significantly different at $P<0.05$ with the overall error rate of analysis of variance controlled by Tukey-Kramer adjustment.

${ }^{x}$ Industry standard pruning referring to a clock face: if the palm is viewed in profile, the canopy would begin at the 10 o'clock position and end at the 2 o'clock position.

Table 6. Number of total fungal cfu (saprophyes and palm pathogens) and number of palm-pathogenic fungi on a selective medium removed from a saw blade flamed after cutting infected palm petioles.

\begin{tabular}{lcc}
\hline $\begin{array}{l}\text { Flaming } \\
\text { treatment }\end{array}$ & $\begin{array}{c}\text { Total } \\
\text { cfu (no.) }\end{array}$ & $\begin{array}{c}\text { Total } \\
\text { pathogens } \\
(\text { no. })^{\mathrm{y}}\end{array}$ \\
\hline No flaming & $42 \mathrm{a}^{\mathrm{x}}$ & $17 \mathrm{a}$ \\
$10 \mathrm{~s}$ & $2 \mathrm{~b}$ & $1 \mathrm{~b}$ \\
$20 \mathrm{~s}$ & $0.4 \mathrm{~b}$ & $0.1 \mathrm{~b}$ \\
$40 \mathrm{~s}$ & $0.3 \mathrm{~b}$ & $0 \mathrm{~b}$ \\
$P$ value & $<0.0001$ & $<0.0001$ \\
\hline
\end{tabular}

${ }^{\mathrm{z}}$ Mean of all fungal cfu; $\mathrm{n}=18$ per treatment (three petioles, three cuts, two plates each).

Total pathogens is the mean of all putative palmpathogenic fungi (canary island date palm wilt and pink rot).

${ }^{x}$ Means followed by the same letter within a column are not significantly different at $P<0.05$ with the overall error rate of analysis of variance controlled by Tukey-Kramer adjustment.
MFP transplanted from l-gal containers reached statistically similar heights of 6.4 and $6.5 \mathrm{~m}$ after " 10 and 2 " pruning and no pruning, respectively (Table 5). Palm height after complete leaf removal was $43 \%$ less than " 10 and 2 " pruning and no pruning treatments $[P<0.0001$ (Table 5)].

SAw SAnitation. A duration of flaming even as short as $10 \mathrm{~s}$ significantly reduced total fungal colonies and palm pathogenic fungi by $95 \%$ as recovered on a selective medium (Table 6). Palm pathogenic fungi were eliminated with $40 \mathrm{~s}$ of flame exposure (Table 6).

\section{Conclusions}

Reduction of photosynthetic area reduces the ability of some palms to grow and produce; even slight decreases in green leaf number have been associated with decreased yield in oil palms (Corley and Hew, 1976). By contrast, in our studies, the industry standard " 10 and 2 " pruning did not reduce leaf production and growth compared with unpruned palms. Extensive pruning that left only the four newest leaves, however, reduced petiole and blade length of subsequent leaves of MFP. Generally, we observed that when more leaves are pruned from more mature MFP, the shorter the petiole and the blade length on leaves produced later.

Complete leaf removal at regular intervals in these experiments limited leaf production, leaf size, or palm height of CFP and young and more mature MFP, but not of windmill palm or queen palm. We were likely able to observe pruning effects on MFP because this species may produce many leaves in a relatively short period (over 50 leaves per year).

At Long Beach, only palms that received complete pruning died, perhaps because the combination of complete pruning and the relatively cool and humid environment outside its native host range increased disease susceptibility. More severe pruning may have also increased the number of wounds, allowing infection to occur. Frequent and severe pruning exacerbates the difficulties of growing this palm in coastal California and does not provide a reduction in diamond scale disease (Downer and Hodel, 2007). Pruning of CFP in
California should be limited to removal of dead fronds only.

The high frequency of pruning in these studies, every 3 to 4 months, is not unseen in landscapes, but also is not practical for most situations. Frequent and severe pruning will likely limit growth of vigorous species in the landscape. We propose that less frequent leaf removal would moderate MFP and CFP response to pruning. Unpruned palms would be expected to grow the fastest.

Because leaf removal in palms is rarely limited to only brown leaves, it is prudent to sterilize saws between trees when working with palms susceptible to pruning-tool-borne diseases. We found that using a portable torch to flame the saw blade was an effective and rapid method of saw sterilization. We suggest brushing debris from the saw teeth before flaming and to flame until any remaining debris turns to ash, a process that takes only a few seconds. The time necessary to sanitize saw blades can therefore be reduced from minutes to seconds and soak-solutions that require disposal and cleanup are eliminated with the flaming method. Increasing our understanding of palm response to leaf removal and how to minimize unintended consequences of pruning such as the spread of disease is an important part of improving care and maintenance of palms.

\section{Literature cited}

Broschat, T.K. 1991. Effects of leaf removal on survival of transplanted sabal palms. J. Arboriculture 17:32-33.

Broschat, T.K. 1994a. Effects of leaf removal, leaf tying, and overhead irrigation on transplanted pygmy date palms. J. Arboriculture 20:210-213.

Broschat, T.K. 1994b. Removing potassiumdeficient leaves accelerates the rate of decline in pygmy date palms. HortScience 29:823.

Broschat, T.K. and A. Meerow. 2000. Ornamental palm horticulture. University Press of Florida, Gainesville, FL.

Corley, R.H.V. and C.K. Hew. 1976. Pruning, p. 308-313. In: R.H.V. Corely, J.J. Hardon, and B.S. Wood (eds.). Oil palm research, Elsevier, New York.

Downer, A.J. and D.R. Hodel. 2007. Leaf removal from Washingtonia filifera does not prevent infection by Phaeochoropsis 
neowashingtoneae but does predispose palms to early death from Gliocladium vermoeseni. HortScience 42:978(Abstr.).

Downer, A.J., J. Uchida, D.R. Hodel, and M.L. Elliot. 2009. Lethal palm diseases common in the United States. HortTechnology 19:710-716.
Elliot, M.L. 2006. Fusarium wilt of canary island date palm. Univ. Florida Inst. Food Agr. Sci. Fact Sheet PP-215/PP-139, 1 June 2009. <http://edis.ifas.ufl.edu/PP139>.

Elliot, M.L., T.K. Broschat, J.Y. Uchida, and G.W. Simone. 2004. Compendium of ornamental palm diseases and disorders. APS Press, St. Paul, MN.
Hodel, D.R. 1999. Pruning palms. Principes 43:99-100.

Robinson, M.L. 2004. Pruning palm trees. Univ. Nevada Coop. Ext. Publ. SP-04-16. 